\title{
Chapter 9 \\ The Public Sphere, Mass Media, Fashion and the Identity of the Individual
}

\author{
Christian Huck
}

The public sphere is now a well-established notion in eighteenth-century studies, ${ }^{1}$ especially when it comes to analyzing periodicals like The Tatler and The Spectator (Newman, 21-4). Most of these studies refer - rather uncritically, as J.A. Downie has recently shown $(2005,58-79)$ - to Jürgen Habermas's classic political study The Structural Transformation of the Public Sphere, which was written 45 years ago. In this chapter, I would like to re-examine Habermas's concept in detail and take a specific look at the role Habermas ascribes to the mass media in the emergence of a public sphere - an aspect largely misconstrued by Habermas, as I will argue. The topic I have chosen to question the workings of the public sphere and mass media directly opposes Habermas's grave, apparently rational, male realm of politics: it is the ephemeral, apparently irrational mundus muliebris of fashion. As we will see, such a shift in focus might lead to a different understanding of the public (sphere) than that of Habermas. This new understanding will also make it possible to reconsider the role of the public (sphere) in the construction of individuals' identities. Schematically, my argument will revolve around the following oppositions:

\begin{tabular}{|l|l|l|}
\hline & Old: Habermasian Public & New: Popular Public \\
\hline Typical Topic & Politics & Fashion \\
\hline Aim & Consensus & Distinction \\
\hline Mode & Rational-Critical Conversation & $\begin{array}{l}\text { Affective Compact } \\
\text { Impression }\end{array}$ \\
\hline Medium & Interaction & Mass Media \\
\hline Form & Letter & Advertisement \\
\hline Place & Coffee-House & 'Sphere' of Expectations \\
\hline Identity & Prerequisite & Consequence \\
\hline
\end{tabular}

It should have become clear by now that the following discussion will be theoretical in perspective. Historical studies, like any other form of science, cannot

1 I am not only indebted to all members of the research network 'Mediating Identities: Medialisierung und Vermittlung von Identitäten im England des 18. Jahrhunderts' for invaluable discussions of earlier incarnations of the thoughts presented here, but also, and especially, to Anna Christina Giovanopoulos and Annette Pankratz for discussing 'Öffentlichkeit' (public sphere). 
be conducted without a theoretical framework. Sometimes, we are unaware of the distinctions we draw before we search for material, select and interpret it; some even think that we should just let the sources speak for themselves. Nevertheless, no material can speak for itself: it can only answer to questions we ask. And these questions we ask are dependent on our present preconceptions of bygone societies and their historical development; as every hermeneutic endeavour, historical studies begin with a Vorurteil (prejudice). Many studies of the eighteenth-century public sphere have started out from those conceptions outlined by Habermas; as mentioned above, most of these studies found fault in Habermas's description of the eighteenth century and revealed his preconception as a prejudice. However, by exposing Habermas's approach as ideological, it seemed easy to claim a commonsense, bias-free position for oneself. I do not think such a position is possible: the hermeneutic Vorurteil can never be overcome entirely; it can only be adequately reflected and adjusted. Rather than claiming to work without all preconceptions, one should, I think, try to explicate one's theoretical framework as precisely as possible. If there really are too many findings that cannot be integrated into Habermas's model, one should look for a new model that might be better suited to give meaning to new historical evidence. It is such a new theoretical framework that I want to propose here. In order to do so, a meticulously detailed examination of Habermas's framework is necessary to find out which theoretical decisions led to the shortcomings of his approach. Following this re-examination, I will try to construct a new framework that avoids Habermas's shortcomings. Of course, this new theoretical framework will only be as good as the extent to which it is able to integrate historical evidence and extricate meaningful answers from these sources. Unfortunately, however, there is not enough space here to put the new framework to the test - that will have to be done elsewhere. ${ }^{2}$

\section{The 'Public Sphere' and Its Media}

First published in German in 1962, it took until 1989 for Habermas's Strukturwandel der Öffentlichkeit to be published in English as The Structural Transformation of the Public Sphere. However, despite it having taken so long for the complete work to appear in English, a summarized version of Habermas's concept had been published 15 years earlier by the New German Critique under the title of "The Public Sphere: An Encyclopedia Article', which was a translation of a 1964 entry to the Fischer-Lexikon Staat und Politik.

This quick glance at the publishing history reveals at least two points that are worth highlighting. First of all, Habermas's account of the public sphere is written from a perspective of loss. The liberal bourgeois public sphere that Habermas believes to have emerged in the eighteenth century has long been transformed, or corrupted; the historical image of this public sphere functions mainly as an ideal

2 For a more materially saturated engagement with this new framework, see Huck 2010. 
for the current state of post-World War II crisis in Habermas's political critique of the present. Habermas, after all, is not a historian but a political theorist. Secondly, as the journey from Staat und Politik to New German Critique indicates, Habermas's theory of the political public sphere has been turned - not necessarily by Habermas himself, but by editors and adepts - into the foundation for studies of cultural phenomena. Although Habermas refers to central works of cultural publicity such as The Tatler and The Spectator (the 'literary public sphere', as he calls it), these are nothing more than preliminary steps towards his definition of a 'political public sphere'. The simple question that arises from this is whether Habermas's (idealistic) concept of the political public sphere is an adequate tool to analyze the (cultural) effects of The Tatler, The Spectator and similar papers. ${ }^{3}$

In his encyclopaedia article Habermas states that "by "the public sphere" we mean first of all a realm of our social life in which something approaching public opinion can be formed' (Habermas 1974, 49). According to Habermas, 'public opinion', 'arising from the consensus of private individuals engaged in public discussions' (ibid., 54; my emphasis), is the designation, and the fate, of the public sphere. The function of this public opinion is defined precisely: 'The expression "public opinion" refers to the task of criticism and control which a public body of citizens informally [...] practices vis-à-vis the ruling structure organized in the form of a state' (ibid.). The public sphere, then, is something that allows or enables those that are not part of the official state to form an (unofficial) opposition, in that 'a portion of the public sphere comes into being in every conversation in which private individuals assemble to form a public body' (ibid., 49). These 'private individuals' are precisely those 'who were excluded from public authority because they held no office' (ibid., 51), but nonetheless, as 'private individuals' had a legitimate interest in the 'publicly relevant sphere of labor and commodity exchange' (ibid., 52). Does this extend to all individuals? It appears so, since 'access [to the public sphere] is guaranteed to all citizens' (ibid., 49). In this sense, the public opinion of the public sphere is merely an 'informal' equivalent, or supplement, of formal 'periodical elections' (ibid.); the public sphere as a whole is 'a sphere which mediates between society and state' (ibid., 50; my emphasis): via public opinion the public body is enabled to supervise public authority (cf. ibid., 49). Here, the public sphere is itself a medium and, as we will see, does not need another medium: it comes into being when private individuals come together.

How is the 'public opinion' formed in the 'public sphere' by the 'public body'? 'Citizens behave as a public body when they confer in an unrestricted fashion that is, with the guarantee of freedom of assembly and association and the freedom to express and publish their opinions - about matters of general interest' (ibid.). It is of central importance that Habermas's 'public sphere' consists of personal

3 This is not to say that the cultural cannot be political, or that there is no "political culture'; nonetheless, analytically, both realms work according to different sets of rules, and in order to analyze their interplay and their overlapping it might be best to first note these differences. 
gatherings (in coffee-houses, clubs or salons), because it is only here that we can find the civilizing, or rather rationalizing, effects at work, as these are a product of (free) social interaction. Such a 'reasoning public' (ibid., 50) can thus overcome personal (idiosyncratic) opinions and prejudices in free interactional discourse. On the basis of publicly accessible information - a necessary prerequisite - in publicly accessible assemblies, the public body is enabled to control political affairs: 'the process of making proceedings public (Publizität) was intended to subject persons or affairs to public reason, and to make political decisions subject to appeal before the court of public opinion' (ibid., 55). Throughout the eighteenth century the 'public' was thought of in interactional terms, in terms of co-presence: the public was a place where individuals came together in person to discuss public matters. And it is important to emphasize that in Habermas's view, 'private individuals' exist as private individuals with private opinions before they come together. Everything else is grounded upon the preceding existence of such individuals and their personal interests in labour and commodity exchange.

There is one element of Habermas's theory that I have neglected so far: the role of (mass) media. In the genealogy of the public sphere that Habermas provides, he elaborates upon the 'important role' (ibid., 53) newspapers play in the formation of public opinion. Taking the developments in Britain as a model example in his more extensive monograph, he highlights precisely those publications that have long been an integral part of English studies, and particularly eighteenth-century studies: 'the Tatler, the Spectator, and the Guardian' (Habermas 1989, 43). However, while the importance of these publications is emphasized historically - and quite rightly so - their place in the systematic account is less prominent. In his encyclopaedic approach, the reference to media is brief: "In a large public body this kind of communication [at 'free' assemblies] requires specific means for transmitting information and influencing those who receive it. Today newspapers and magazines, radio and television are the media of the public sphere' (Habermas 1974, 49). Similarly, in the longer historical exposition, the emergence of newspaper is cast as a reaction to the growth of the public sphere, not as its instigator: 'When Addison and Steele published the first issue of the Tatler in 1709, the coffee-houses were already so numerous and the circles of their frequenters already so wide, that contact among these thousandfold circles could only be maintained through a journal' (Habermas 1989, 42).

If there had been big enough coffee-houses, it appears, full of well-informed citizens, newspapers would have been unnecessary for the formation of a public opinion in the public sphere by the public body on the basis of public information. However, simply because of the sheer numbers of 'private individuals' in eighteenth-century London, newspapers became necessary for ensuring that all members of the public were given access to information. For Habermas, the moral weeklies were a platform for negotiations between individuals who were looking for the same 'agreement and enlightenment' (ibid., 43) as it was pursued and practised in the coffee-houses; newspapers were nothing more than an extension 
of interaction in co-presence: 'One and the same discussion transported into a different medium was continued in order to re-enter, via reading, the original conversational medium' (ibid., 42).

\section{Mass Media}

As I tried to explicate, Habermas's preference for interactional situations grants no more than a supplementary role to the mass media: conversation is 'original', newspapers are a 'continuation'." 'The press', Habermas elaborates, 'remained an institution of the public itself, effective in the manner of a mediator and intensifier of public discussion, no longer a mere organ for the spreading of news but not yet the medium of a consumer culture' (Habermas 1974, 53). In its heyday, according to Habermas, the press worked as a kind of catalyst. Newspaper makers provided the necessary information for private individuals, who would then discuss it in the coffee-houses; these discussions, then, could be reflected in the papers. As a catalyst the newspapers added nothing to the information they secured and remained neutral, without an agenda of their own: they were merely, noiselessly, mediating.

As the antagonist of this neutral function, Habermas identifies 'consumer culture' as such: 'rational-critical debate had a tendency to be replaced by consumption, and the web of public communication unravelled into acts of individuated reception, however uniform in mode' (Habermas 1989, 161). This mode of consumption, which Habermas identifies as typical of mass culture, apparently 'leaves no lasting trace; it affords a kind of experience which is not cumulative but regressive [sic]' (ibid., 166). ${ }^{5}$ The medium can no longer fulfil its function when it is consumed in 'individuated' (albeit 'uniform') form. Information received in this mode, according to Habermas, cannot (re-)enter the interactional, rational discussion of the coffee-house - it is lost in consumption. Habermas even gives a date for when the mediating function of 'the press' was transformed into a commercial one: 'In England, France, and the United States the transformation from a journalism of conviction to one of commerce began in the 1830 s at approximately the same time.' From then on, 'private interests' began to rule the mass media. Before, 'the publishers insured [sic] the newspapers a commercial basis, yet without commercializing them as such' (Habermas 1974, 53). What had instigated the emergence of a public sphere - capitalism in the form of 'commodity exchange' - now came to swallow it.

It is not exactly clear what Habermas means by a 'commercial basis' that is not 'commercializing', but presumably he means that commerce was merely a

4 Habermas refers to readers' letters as proof for his thesis, and indeed these played an important role in early stages of the newspaper genre. However, they are an attempt to familiarize a new medium rather than an adequate reflection of the medium's structural status - many wrote letters, but most did not; they merely consumed.

5 Cf. Calhoun, 23-4. 
means to the editorial end, the material basis for the newspaper to function as a neutral medium. Whether such a situation ever existed is an important question but difficult to answer. According to recent historical studies, politically motivated parties subsidized most periodicals of the early eighteenth century (Downie 1993). The publishers of these newspapers were dependent on financial backing, and their papers were surely engaged in providing not simply the factual basis for rational discussions, but biased rhetorical opinions that eventually led to mudslinging and a two-party dissensus rather than a consensual public opinion. This can hardly be Habermas's ideal of a free press. Neither, presumably, does he mean those commercially successful publications with pornographic, voyeuristic and spectacular content, which he (deliberately?) ignores in his account of eighteenthcentury media. However, the papers Habermas refers to as positive examples The Tatler, The Spectator, The Guardian - seem to have been the only ones that were able to work autonomously, independently of direct subsidies. Here, indeed, 'the publishers ensured the newspapers a commercial basis'.

But how were they able to do so? According to Daniel Defoe, the commercial basis of independent newspapers could be ensured neither by sales nor subscription. In an answer to a reader's letter complaining about the increase of advertisements in his paper, he declares: 'The Author lets him know, that first of all 'tis apparent the Principal Support of all the Publick Papers now on Foot, depends upon the Advertisements. ${ }^{96}$ In order to be public, that is, open to all, newspapers needed someone else to pay the bill for the delivery of information: advertisers. Newspapers were and are more than just printed conversation, or fodder for sparking and continuing rational debates. To communicate via printed material produces financial costs that do not occur when talking to those present only paper and ink have to be bought, machines have to be purchased and maintained and so on. If readers were asked to pay the full price for these costs, the audience would be (even more) severely restricted and the papers no longer 'publick'. As a consequence, communication is no longer a matter between just two parties: alter and ego, author and reader. Nor is it a mere transportation of interactional discussions into another medium. A third factor has now entered the equation with its own motivations: The medium, from now on, adds a message of its own. Communication, from now on, is triangulated, and it becomes impossible to keep an eye on every party involved: front and back, as we will see, start following different agendas.

There is, of course, a lot to be said about the ways in which information is selected for mass media and how it is published, and much can also be said about the categorical difference between spoken and printed discourse that Habermas seems to ignore. For example, newspapers constantly have to produce (spectacular) news items, and therefore they have a tendency to report in quantities and numbers and prefer topics that have pros and cons, or perhaps entail a conflict (cf. Luhmann

6 Little Review, No. 10 (1705), 37. Michael Harris supports Defoe's assessment from a twentieth-century perspective (19-24). 
$1990,170-82$ ). Instead of simply revealing what had hitherto been unknown to the public, newspapers, as we know today, create a specific version of reality. However, it is not my topic here to investigate the distorting effects of newspapers competing for attention in an embattled market.

Rather, I am interested in finding out what kind of public (sphere) is created by advertising, especially by fashion advertisements, since fashion is the prototypical topic of (popular) mass-mediated communication and a distinguishing feature of newspapers. More than any other paper, The Spectator relied not only on general advertising, but also, and especially, on advertisements for fashionable goods, cosmetics and clothes in particular. ${ }^{7}$ In contrast to Habermas's interpretation, the mass consumption of consumer goods is not a consequence of the rise in production caused by the industrial revolution. The lust for consumption and demand for goods did not have to be artificially created after large corporations increased production - consumption, retailing and production have a much more intricate and entangled history. The public sphere is part of this history, and not something that has been consumed by it. As is well known, The Spectator, The Tatler and other papers excessively reported on questions of fashion, ${ }^{8}$ sometimes even more than about literature, art or even politics. In economic terms, clothes were the second largest expenditure in private eighteenth-century households. The fashions (for example Spectator, No. 478, 1712) and cosmetics (for example Tatler, August 20,1709) criticized and regulated again and again in the essays on the front page of the broadsheets were regularly promoted on a back page that was often completely filled with advertisements. Advertisements, as I want to argue here, encapsulate perfectly the essence of (popular) newspapers and mass media in general: they speak to you, and to you specifically and especially, but they expect no (direct) answer - they explicitly do not want to start a debate, rational or otherwise. Even more importantly, the popular talks to many 'yous' at the same time. It is personal and common at once. ${ }^{9}$

\section{Advertising and Fashion}

As seen above, Habermas situated the political public sphere as a mediator between the interests of 'private individuals' on the one hand and 'the state' on the other. But what oppositional forces are there in cultural matters? Does such a clear-cut opposition exist, as appears to be the case in the political sphere? If there

7 For details of the quantity and quality of advertisements for fashion in The Spectator and The Tatler, see Huck 2007.

8 For The Spectator's stance towards fashion, as it is to be found in the essays, see Mackie.

9 My notion of the popular goes beyond eighteenth-century definitions that situate the popular among so-called common or plebeian people only. Rather, what we can witness in the eighteenth century is an emancipation of popular forms from a well-defined demographic section of society: the popular becomes a semantic open to all forms of discourse. 
are no elections, what is the 'informal' equivalent that reveals the public opinions concerning fashion? What secret knowledge, hitherto kept secret by interested parties, is to be revealed by the media? Is there a private opinion on fashion that individuals can bring to the public body? Is fashion open to discussion?

In the realm of culture there is no direct counterpart that the public body could challenge with its consensual opinion. Instead, the public provides its own opposition; there are no sumptuary laws passed by the state, for example, which the public opinion could supervise. ${ }^{10}$ Taste is something that is discussed among the public itself. Fashion is unofficial, social and inherently public. There are no private fashions and no official ones; a fashion that nobody knows of is not a fashion, nor can fashion be dictated. There are, of course, the institutions Habermas mentions, such as the coffee-houses, literary salons and so on, that facilitate the (rational?) discussion of works of art, books and fashions on the basis of the information provided by the newspapers, and these institutions surely play a role in attempting to create a public opinion about fashion, art, and so on. But are the judgements about 'Culture', resulting from interactional discussions inspired by The Spectator and similar papers, really the central effect and function of those discourses?

For Habermas, at least, everything else would signal decline:

Where works of literature, for example, had previously been appropriated not just through individual reading but through group discussion and the critical discourse of literary publications, the modern media and the modern style of appropriation "removed the ground for a communication about what has been appropriated" [...]. (Calhoun, 23) ${ }^{11}$

This judgement is doubtful in both directions: it is neither sensible to suggest that 'individuated reception' has not been a central mode of reading in the eighteenth century nor reasonable to propose that today's books and films are not eagerly discussed - in fanzines, on fan-sites, in reviews, at parties and so on. However, neither modern-day nor eighteenth-century discussions of works of literature are mere continuations in speech of preceding printed discourses. There are no arguments to be taken up, no single propositions to be extricated. Instead, as I will explain in the following paragraphs, the 'compact impression', as I will call it, of a mass-mediated work forms the basis for further communications.

In any case, it cannot be said that the result of discussions about culture is consensual. More than anything else, fashion is a matter of distinctions, or different judgements and opinions about certain modes of dress. Is there, indeed, any need to produce a consensus about fashion? Who would benefit if there was just one public opinion about fashion and everyone wore the same clothes?

10 Only a few, very specific sumptuary laws, concerning the wearing of highland dress, printed calicoes, or swords, for example, were renewed or even introduced after Jacobean times; general fashions, that is, the cut, colour, and wear of apparel, were not regulated.

11 Calhoun quotes Habermas 1989, 163. 
Aside from some authors of social utopias, no one has ever argued for a uniform dress for every citizen of a state. There were times, of course, when the state attempted to regulate differences in dress. However, at least since the eighteenth century, 'personal appearance is no longer determined by social consensus' - quite the opposite, as the sociologist Gilles Lipovetsky emphasizes:

[Fashion] affronts habits and prejudices; it is violently condemned by church leaders; it is judged ridiculous, inappropriate, and hideous by contemporary chroniclers. The latest vogue is viewed as sublime by the elegant set, as scandalous by the moralists, and as ridiculous by the ordinary honest person; fashion and discordant opinion henceforth go hand in hand. (28)

This disagreement is by no means an involuntary or unintentional effect; the moralists try just as hard as the elegant to distinguish themselves through different (opinions on) fashions. Since the field of cultural capital is a contested realm, a consensus concerning matters of fashion can never be attained. Here, 'Culture' becomes culture - the transparent and transitory cement that binds and regulates society, at least momentarily. Fashion, deemed by many as the medium of compliance, is indeed the perfect example of how the sameness of objects and the divergence of opinions go hand in hand. A consensus about what exists does not imply a consensus about how it is - and this how, the way we see and do things, is what defines culture.

According to Niklas Luhmann, who was Habermas's great antagonist in German post-war sociology and is still largely unknown to English-speaking nonsociologists, the function of the mass media is precisely to produce objects that can be taken for granted in (further) communications, irrespective of individuals' perspectives regarding them:

It seems that interest in [the various] programmes [of the mass media] lies in being presented with a credible reality, but one which does not have to be subject to consensus. Despite living in the same world (there is no other), viewers are not expected to join in any consensus of opinion. They are at liberty to agree or disagree. (Luhmann 2000, 60)

One can talk about this 'credible reality' (defined as consisting of things, but also schemata, scripts, types and so on) without relying on or getting involved with other people's idiosyncratic views.

Without necessarily having to be believed, mass-mediated impressions of reality inform the reader of what others have also been exposed to, providing common ground for future (inter-)action. People do not start discussing whether hoop petticoats actually exist, even if few have ever actually seen one in real life, but they probably all have different opinions on the matter. Mass-mediated impressions of reality can produce a credible reality simply because we expect others to know about them as well: 'Attention is paid to what is emitted just because it has been emitted and may be worthy of consideration; the emission makes it 
part of a background reality, frames of normality and a horizon of expectations' (Helmstetter, 54; my translation). This, as Elena Esposito has pointed out, seems especially true when it comes to fashion. Mass media 'provide the individual with fashion styles in the form of general semantic tendencies $[\ldots]$, which the individual can follow or oppose' (Esposito, 168; my translation). Therefore, the possibilities of deviance only come into existence as a flipside of conformity. Mass media present/establish a certain behaviour, or appearance, as is realistically to be expected (to be accepted), yet there is always the possibility that readers use the knowledge specifically to differentiate themselves from such expectations.

This (popular) public sphere, then, is not a place were people come together to engage in rational-critical discourse; this public sphere is a sphere in the more elusive, almost celestial sense. It is the shared 'background reality' (Luhmann 2000,65 ), the 'latent everyday culture' (ibid., 66) that remains un-uttered and un-contested, the knowledge that one expects others to expect oneself to have. Such a sphere is open to everyone who can be expected to have access to mass media, regardless of whether they choose to take advantage of it. The idea that what is published in the mass media is out in the open, potentially accessible to everyone, becomes more important than the question of who actually empirically - accesses it. The 'reality of the mass media' is therefore real because it has real consequences, because it informs people's actions, not because it (mis-)represents a real reality (Luhmann 1997, 1102; cf. Müller 2006, 192).

In this sense, Habermas is perfectly right, willingly or not, in claiming that 'the public held up a mirror to itself' (Habermas 1989, 43) with the help of newspapers. Indeed, the public cannot see reality in this mirror, but an assembly of observers looking for reality - the mirror enables the observation of observers (Luhmann 1990,181 ). Therefore, it matters little how real the image of reality they see is; it is enough to know, or even to believe, that others see the same image. And, as Habermas's metaphor of the mirror also reveals, the newspapers are stared at rather than being active agents in critical-rational discourse. The glance into the mirror of the mass media provides the spectator with popular 'compact impressions' (Luhmann 1997, 579; cf. Zorn). In other words, they are presented with condensed, easily accessible, highly charged and alluring impressions of reality that are imagined to be shared with others.

But although the public sphere is potentially open to everyone who has access to mass media, the background reality is not the same for every reader, as it is determined by their choice of reading material, their needs and interests, their economic means and hermeneutic skills, other forms of knowledge and so on. Only the most popular, or fashionable, utterances become part of everyone's reality, and not everything that is made public becomes that popular. As a consequence, the public sphere cannot be analyzed by examining interactional institutions, nor can it simply be analyzed by examining sales figures and the size of readerships. Instead, one has to enter the much more elusive realm of suppositions of suppositions and expectations of expectations, and as these remain unattainable to (historical) analysts, they can only try to determine the popularity of mediated utterance. 
What is in fashion, what can be expected to be expected, is not hitherto secret information that simply has to be publicized. It only exists once it is public, and it becomes effective once it is popular. Which forms and topics become popular at a certain time and place is as difficult to determine for the cultural analyst as it is to produce them.

However, to make things popular is precisely the task that Addison ascribed to advertising when he wrote that 'the great Skill in an Advertizer, is chiefly seen in the Style which he makes use of. He is to mention the universal Esteem, or general Reputation, of Things that were never heard of' (The Tatler, No. 224, 1710). Advertisements especially, and the mass media in general, try to convince the consumer/reader that what s/he knows (and likes), or rather, should know (and like), is known (and liked) by everyone else already (cf. Helmstetter). Advertisements, once again, do not enable the observation of reality (which here would be the inherent qualities of the goods in question), but rather the (imaginary) observation of other observers:

All Gentlemen may be Furnished with Cloaths, well made and fashionable at 31.15s. per Suit of Drugget and Saggatee, and Spanish Dragget Suits lined with Durants at $41.15 \mathrm{~s}$ per Suit; Livery Suits with Shag Breeches at $41.10 \mathrm{~s}$. per Suit, lace Liveries with Worstead Lace at 61.10s per Suit; fine Cloath Suits at 71. per Suit by Tho. Salkild [?] in Earls Court Bow-street, Covent Garden [...]. ${ }^{12}$

'Fashionable' is indeed just another word for the fact that something is liked by others, even though one might not have heard about it. It is obvious that such an advertisement does not lead to rational-critical discourse in Habermas's sense, but does it leave no other option but passive-regressive consumption? What is the consumer to make of the compact impressions delivered by the mass media, made popular in the public sphere? Is s/he a mere victim of (hidden) capitalist persuaders?

\section{Individuals}

In Habermas's conception, individuals come together as private individuals with individual opinions who then form a consensual public opinion through rational discourse. Following Adorno, Habermas sees the mass media and their homogenizing tendencies ('uniform') as a threat to the individuality of individuals. For Luhmann, on the other hand, the apparent homogeneity of the mass media does not necessarily mean less individuality for the individual. On the contrary, standardization and individuality can be seen as two sides of the same coin, as Elizabeth Eisenstein assumes in her analysis The Printing Revolution: 'In this regard one might consider the emergence of a new sense of individualism as a by-product of the new forms of standardization. The more standardized the type,

12 The Post Man, No. 1876, 1710; again in June, September and November. 
indeed, the more compelling the sense of an idiosyncratic personal self' (56). For Habermas, private individuals are endowed with diverse identities that they are able to, and have to, shed when they enter critical-rational debates, whereas for Luhmann, individuals are undifferentiated entities before they encounter mass media and consequently 'individualize'. Communication that aims at coercing people into forming a consensus can simultaneously signal to the addressee that $\mathrm{s}$ /he has the freedom to think differently about a certain topic. Only by realizing that they are asked to consent do individuals become aware of their power to disagree, and what has hitherto just been an idiosyncratic thought now becomes an individual opinion on a shared topic worthy of becoming the foundation of an individual identity. The public sphere, in this sense, does not facilitate consensus; it presents possibilities, a space to negotiate one's relation to a shared (imaginary) culture. Individuals are able to position themselves vis-à-vis this culture: 'Nothing defines our world more precisely and through nothing else do we become more individual than by the choice of our newspaper [...] and the way in which we read it' (Baecker, 93; my translation).

However, the individual is at the same time positioned by the compact impressions through which (s)he distinguishes him-/herself. Mass media define those standards from which it becomes possible to deviate, the (limited and legitimated) possibilities from which to choose: 'You can have many opinions, but only within this spectrum and this horizon. And this is obviously invaluable for the behavioural security of humans' (Baecker, Bolz and Hagen, 127; my translation). Fashion enables a peculiarly modern - and it may even be doubtful whether there is any other - version of individuality and individual identity, which is actually a result of the proliferation of the mass media, rather than something needing to be defended against it:

As a collective constraint, fashion actually left individuals with relative autonomy in matters of appearance; it instituted an unprecedented relation between individuals and the rule of society. Fashion's distinguishing feature was its imposition of an overall standard that nevertheless left room for the manifestation of personal taste. One must look like other people, but not exactly; one must follow trends and signal one's own taste. (Lipovetsky, 33; my emphasis)

\section{Epilogue: Cultural Communications}

Habermas's claim that consumption - of newspapers and informed by newspapers - is a passive, even 'regressive' act, replacing critically engaged conversations, has to be refuted. Surely, one cannot answer mass-mediated communications as one can in an interactional conversation, but there is still room for an active appropriation that Habermas denies and Luhmann ignores. The compact impressions that the mass media leave behind can be answered by another compact impression: consumers choose to wear these clothes and not those, they 
adorn themselves in what feels appropriate from the selection on offer. The mass media can, in turn, observe these compact impressions of individuals' positionings towards a shared (imaginary) culture in the form of trends and charts, which can then create new compact impressions that the consumers can appropriate anew. Such communication in the form of compact impressions is, of course, not a rational discourse; instead, it leaves room for affections, aversions and desires. The regulation of such communication works according to feedback loops, producing a sense of normality, and analyzing such exchanges becomes an equally endless task of deciphering highly dense, constantly changing images (pictorial as well as textual, but also various forms of design). However, I would like to state here that such communications via compact impressions are also part of the public sphere, and they should be taken into account when analyzing the culture of eighteenth-century Britain. 


\section{Bibliography}

Addison, Joseph (1713), Cato: A Tragedy, 2nd edn (London: J. Tonson).

Addison, Joseph and Richard Steele (1965, 1711-1714), The Spectator, Donald Bond (ed.), 5 vols (Oxford: Clarendon).

The Albion Mills on Fire (1791), (London: British Museum Prints \& Drawings), Reg. No. 1868.0808.6016.

Althusser, Louis (2001), 'Ideology and Ideological State Apparatuses', in Vincent B. Leitch, et al. (eds), The Norton Anthology of Theory and Criticism (New York and London: Norton), 1483-1509.

Altick, Richard D. (1978), The Shows of London (Cambridge, MA: Belknap).

Anderson, Benedict (1991), Imagined Communities: Reflections on the Origin and Spread of Nationalism, rev. edn (London: Verso).

Baecker, Dirk (2005), Kommunikation (Leipzig: Reclam).

Baecker, Dirk, Norbert Bolz, and Wolfgang Hagen (2005), 'Über das Tempo der Massenmedien und die Langsamkeit ihrer Beobachter', in Wolfgang Hagen (ed.), Warum haben Sie keinen Fernseher, Herr Luhmann? Letzte Gespräche mit Niklas Luhmann (Berlin: Kadmos), 109-44.

Bailey, Margery (ed.), (1951), Boswell's Column: being his Seventy Contributions to The London Magazine under the pseudonym The Hypochondriack (London: William Kimber \& Co.).

Baker, John Haydn (2004), Browning and Wordsworth (Madison: Fairleigh Dickinson University Press).

The Baker's Glory, or, The Conflagration (1791) (London: British Museum Prints \& Drawings), Reg. No. 1868, 0808.6017.

Bale, John (2004), Running Cultures: Racing in Time and Space (New York: Routledge).

Balibar, Etienne (2006), 'My Self and My Own: One and the Same?', in Bill Maurer and Gabriele Schwab (eds), Accelerating Possession: Global Futures of Prosperity and Personhood (New York: Columbia University Press), 21-44.

Bannet, Eve Tavor (2000), Domestic Revolution: Enlightenment Feminisms and the Novel (Baltimore: Johns Hopkins University Press).

Barker, Jane (1713), Love Intrigues: or, The History of the Amours of Bosvil and Galesia as Related to Lucasia, in St Germains Garden. A Novel. Written by a Young Lady (London: E. Curll and C. Crownfield).

- (1723), A Patch-Work Screen for the Ladies; or, Love and Virtue Recommended: in a Collection of Instructive Novels. Related after a Manner Intirely new, and Interspersed with Rural Poems, Describing the Innocence of a Country-Life (London: E. Currll and T. Payne). 
Barker, Robert (1988, 1792), London from the Roof of the Albion Mills (Etching by Frederick Birnie), in Hyde, 18-19.

(1993, 1799), 'Constantinople', in Sehsucht, 133 4.

Barker-Benfield, G.J. (1996), The Culture of Sensibility: Sex and Society in Eighteenth-Century Britain (Chicago: University of Chicago Press).

Barrell, John (1983), English Literature in History, 1730-80: An Equal, Wide Survey (London: Hutchinson).

- (1989), "The Dangerous Goddess": Masculinity, Prestige, and the Aesthetic in Early Eighteenth-Century Britain', Cultural Critique 12: 101-31.

- (2000), Imagining the King's Death: Figurative Treason, Fantasies of Regicide, 1793-1796 (Oxford: Oxford University Press).

Benedict, Barbara M. (1994), Framing Feeling: Sentiment and Style in English Prose Fiction 1745-1800 (New York: AMS).

Benjamin, Walter (1968), 'On Some Motifs in Baudelaire', in Illuminations, trans. Harry Zohn (New York: Schocken), 155-200.

Benwell, Bethan and Elizabeth Stokoe (2006), Discourse and Identity (Edinburgh: Edinburgh University Press).

Blackstone William (1979, 1765-1769), Commentaries on the Laws of England, Stanley N. Katz (ed.), 4th edn (Chicago: University of Chicago Press).

Böker, Uwe (2002a), 'Angelsächsische Geltungsgeschichten der frühen Neuzeit: Die Legitimierung der Ancient Constitution und das Prinzip der Rule of Law', in Gert Melville and Hans Vorländer (eds), Geltungsgeschichten: Über die Stabilisierung und Legitimierung institutioneller Ordnungen (Köln: Böhlau, 2002), 203-41.

(2002b), 'Institutionalized Rules of Discourse and the Court Room as a Site of the Public Sphere', in Uwe Böker and Julie Hibbard (eds), Sites of Discourse - Public and Private Spheres - Legal Culture (Amsterdam: Rodopi), 35-66.

Borges, Jorge Luis (1975, 1954), A Universal History of Infamy, trans. Norman Thomas Di Giovanni (London: Penguin).

Boswell, James (1770), 'Remarks on the Profession of a Player', London Magazine 39 (August-October).

Boulukos, George (2008), The Grateful Slave: The Emergence of Race in Eighteenth-Century British and American Culture (Cambridge: Cambridge University Press).

Bourdieu, Pierre (1984), Distinction: A Social Critique of the Judgement of Taste (London: Routledge).

Braithwaite, Alfred W. (1962/1964), 'Early Friends' Experiences with Juries', Journal of the Friends' Historical Society 50: 217-27.

- (1972), 'Three Hundred Years Ago: The Penn-Meade Trial and Its Sequel', Quaker History 61: 3-15.

Braudy, Leo (1970), 'Fanny Hill and Materialism', Eighteenth Century Studies, 4: $21-40$. 
Brewer, John (1997), The Pleasures of the Imagination: English Culture in the Eighteenth Century (London: HarperCollins).

Brissenden, R.F. (1974), Virtue Rewarded: Studies in the Novel of Sentiment from Richardson to Sade (London: Macmillan).

British Trials, 1660-1900 (1993), microfiche edition (Cambridge: ChadwyckHealey).

Brodsley, Laurel (1993), 'Defoe's Journal of the Plague Year: A Model for Stories of Plagues', in E.S. Nelson (ed.), AIDS: The Literary Response (New York: Twayne), 11-22.

Brooke, Frances $(1997,1777)$, The Excursion, Paula R. Backscheider and Hope D. Cotton (eds) (Lexington: University Press of Kentucky).

Brooks, David (1992), 'Daniel Defoe's A Journal of the Plague Year', in Peter Hinton (ed.), Disasters: Image and Context (Sydney: Sydney Studies), 167-85. Brunken, Otto (1988), 'The Novel as Controversial Reading Material for Young People in the 16th, 17th and 18th centuries', Phaedrus 13: 40-48.

Buddemeier, Heinz (1970), Panorama, Diorama, Photographie: Entstehung und Wirkung neuer Medien im 19. Jahrhundert (Munich: Fink).

Burgess, Miranda (2009), 'Nationalism in Romantic Britain and Ireland: Culture, Politics, and the Global', in Jon Klancher (ed.), A Concise Companion to the Romantic Age (Oxford: Blackwell), 77-98.

Burke, Edmund (1968), The Correspondence: January 1792-August 1794, vol. VII, P.J. Marshall and John A. Woods (eds) (Cambridge: University Press). (1993, 1790), Reflections on the Revolution in France, L.G. Mitchell (ed.) (Oxford: Oxford University Press).

Burke, Edmund III and David Prochaska (eds) (2008), Genealogies of Orientalism: History, Theory, Politics (Lincoln: University of Nebraska Press).

Burke, Helen (2003), Riotous Performances: The Struggle for Hegemony in the Irish Theater, 1712-1784 (Notre Dame: University of Notre Dame Press).

(2005), 'Eighteenth-Century Theatrical Touring and Irish Popular Culture', in Nicholas Grene and Christopher Morash (eds), Irish Theatre on Tour (Dublin: Carysfort Press), 219-32.

(2007), 'Acting in the Periphery: The Irish Theatre', in Jane Moody and Daniel O'Quinn (eds), The Cambridge Companion to British Theatre, 17371830 (Cambridge: Cambridge University Press), 219-32.

[Burney, Frances] (1990, 1793), 'Brief Reflections Relative to the Emigrant French Clergy', in Claudia L. Johnson (ed.), 'Considerations on Religion and Public Education' [Hannah More] and 'Brief Reflections [...]' (Los Angeles: University of California Press).

Burtt, Shelley (1992), Virtue Transformed: Political Argument in England, 1688 1740 (Cambridge: Cambridge University Press).

Büsch, J.G. (1786), Bemerkungen auf einer Reise durch einen Teil der Vereinigten Niederlande und Englands (Hamburg: Bohn). 
Butler, Judith (1993), Bodies that Matter: On the Discursive Limits of 'Sex' (New York: Routledge).

- (1999), Gender Trouble: Feminism and the Subversion of Identity, 2nd edn (London: Routledge).

Caldeira, Teresa P.R. (1999), 'Fortified Enclaves: The New Urban Segregation', in James Holton (ed.), Cities and Citizenship (Durham: Duke University Press), 114-38.

Calhoun, Craig (ed.) (1996), Habermas and the Public Sphere, 4th edn (Cambridge, MA: MIT Press).

Camden, William $(1637,1586)$, Britain (London: Andrew Hee).

Chetwood, W.R. (1749), A General History of the Stage, from its Origin in Greece down to the Present Time (London).

Claeys, Gregory (ed.) (1995), Politics of English Jacobinism: Writings of John Thelwall (Philadelphia: Pennsylvania State University Press).

Cleland, John (2001, 1749), Fanny Hill; or: Memoirs of a Woman of Pleasure, Peter Wagner (ed.) (London: Penguin).

Clery, Emma (2004), The Feminization Debate in Eighteenth-Century England (Houndmills: Palgrave Macmillan).

Clive, Catherine (1753), The Rehearsal: or, Bays in Petticoats (Dublin).

- (1763), Sketch of a fine Lady's Return from a Rout (LA220), Larpent Collection, Henry E. Huntington Library, San Marino, CA.

- (1765a), The Faithful Irish Woman (LA247), Larpent Collection, Henry E. Huntington Library, San Marino, CA.

- (1765b), Every Woman in Her Humour (LA174), Larpent Collection, Henry E. Huntington Library, San Marino, CA.

- (1973, 1744), The Case of Mrs Clive (Los Angeles: William Andrews Clark Memorial Library).

Cobban, Alfred (ed.) (1960), The Debate on the French Revolution, 1789-1800 (London: A. and C. Black).

Cohn, Bernard S. (2008), Genealogies of Orientalism: History, Theory, Politics (Lincoln: University of Nebraska Press), 102-53.

Coleridge, Samuel Taylor (1956), Collected Letters, vol. 2, 1801-1806, Earl Leslie Griggs (ed.) (Oxford: Clarendon).

Colley, Linda (1996), Britons: Forging the Nation, 1707-1837, 3rd edn (London: Vintage).

- (2002), Captives: Britain, Empire and the World, 1600 1850(London: Cape). Colls, Robert (2002), Identity of England (Oxford: Oxford University Press).

Copeland, Edward W. (1972), 'Clarissa and Fanny Hill: Sisters in Distress', Studies in the Novel 4: 343-52.

Crane, David (1989), 'Introduction', in Sheridan 1989 (London: A \& C Black): ix-xxvi.

- (1995), 'Satire and Celebration in The Critic', in James Morwood and David Crane (eds), Sheridan Studies (Cambridge: Cambridge University Press), 87-95. 
Crary, Jonathan (1998), 'The camera obscura and its subject', in Mirzoeff, 245-52. Crook, John (1701), 'The Cry of the Innocent for Justice', in The Design of Christianity, with other Books, Epistles, and Manuscripts, of that Ancient Faithful Servant of Christ Jesus, John Crook. To which is Prefixed a Short Account of His Life Written by Himself (London), 146-211.

(1993, 1692), The Cry of the Innocent for Justice: being a Relation of the Tryal of John Crook, and others, at the General Sessions, held in the Old Bayley, London [...] Published for no other end but to prevent Mistakes, and to satisfie all moderate Enquirers, concerning the Dealings and Usages that the said J.C. and others met withal, from the beginning of the said tryals to the end, in British Trials, 1660-1900, no. 628.

Crowley, Patrick (2003), 'Paul Ricoeur: The Concept of Narrative Identity, the Trace of Autobiography', Paragraph: A Journal of Modern Critical Theory 26.3: $1-12$.

Cunningham, Hugh (1995), Children and Childhood in Western Society Since 1500 (London: Longman).

Curtis, T.C. and Arthur William Speck (1976), 'The Societies for the Reformation of Manners: A Case Study in the Theory and Practice of Moral Reform', Literature and History 3: $45-64$.

Daniell, Thomas and William Daniell (1795-1808), Oriental Scenery, 6 vols (London: Longman, Hurst, Rees, Orme, and Brown).

(1810), A Picturesque Voyage to India by the Way of China (London: Longman, Hurst, Rees, Orme, and Brown).

Darby, Wendy Joy (2000), Landscape and Identity. Geographies of Nation and Class in England (Oxford: Berg).

Darton, F.G. Harvey (1982), Children's Books in England: Five Centuries of Social Life, 3rd rev. edn (Cambridge: Cambridge University Press).

Davies, Thomas (1780), Memoirs of the Life of David Garrick, Esq. (2 vols, London).

De Almeida, Hermione and George H. Gilpin (2005), Indian Renaissance: British Romantic Art and the prospect of India (Aldershot: Ashgate).

De Bolla, Peter (2003), The Education of the Eye: Painting, Landscape and Architecture in Eighteenth-Century Britain (Stanford: Stanford University Press).

De Certeau, Michel (1985), 'Practices of Space', in Marshall Blonsky (ed.), On Signs (Oxford: Blackwell), 122-45.

De Mause, Lloyd (ed.) (1976), The History of Childhood (London: Souvenir Press).

De Quincey, Thomas (1985), Confessions of an English Opium-Eater and Other Writings, Grevel Lindop (ed.) (Oxford: Oxford University Press).

Defoe, Daniel (1970, 1722), The Complete English Tradesman: Directing him in the several Parts and Progressions of Trade, 2 vols (repr. New York: Burt Franklin). (1994, 1719), Robinson Crusoe (London: Penguin). 
(2003, 1722), A Journal of the Plague Year, Cynthia Wall (ed.) (London: Penguin).

Derrida, Jacques (1987), 'Devant la loi', trans. Avital Ronell, in Alan Udoff (ed.), Kafka and the Contemporary Critical Performance: Centenary Readings (Bloomington: Indiana University Press), 128-49.

(2004), Dissemination, trans. Barbara Johnson (London: Continuum).

Dirks, Nicholas B. (1994), 'Guiltless Spoliations: Picturesque Beauty, Colonial Knowledge, and Colin Mackenzie's Survey of India', in Catherine B. Asher and Thomas R. Metcalf (eds), Perceptions of South Asia's Visual Past (New Delhi: American Institute of Indian Studies, et al.), 211-32.

Douglas, Mary (1966), Purity and Danger (New York: Praeger Publishers).

Downie, James Allan (1993), 'Periodicals and Politics in the Reign of Queen Anne', in Robin Myers and Michael Harris (eds), Serials and their Readers, 1620-1914 (Winchester: St. Paul's Bibliographies), 45-61.

- (2005), 'Public and Private: The Myth of the Bourgeois Public Sphere', in Cynthia Wall (ed.), A Concise Companion to the Restoration and Eighteenth Century (London: Blackwell), 58-79.

Duncan, Kathryn (2009), Religion in the Age of Reason: A Transatlantic Study of the Long Eighteenth Century (New York: AMS Press).

Dunn, Kevin (1994), Pretexts of Authority: The Rhetoric of Authorship in the Renaissance Preface (Stanford: Stanford University Press).

Dussinger, John A. (1974), The Discourse of the Mind in Eighteenth-Century Fiction (The Hague: Mouton).

Eaves, T.C. Duncan and Ben D. Kimpel (1971), Samuel Richardson: A Biography (Oxford: Oxford University Press).

Edney, Matthew H. (2003), 'Bringing India to Hand: Mapping an Empire, Denying Space', in Felicity A. Nussbaum (ed.), The Global Eighteenth Century (Baltimore: Johns Hopkins University Press): 65-79.

Eger, Elizabeth, Charlotte Grant, Clíona Ó Gallchoir, and Penny Warburton (2001), 'Introduction', in Elizabeth Eger et al. (eds), Women, Writing and the Public Sphere: 1700-1830 (Cambridge: Cambridge University Press), 1-23.

Eisenstein, Elizabeth L. (1983), The Printing Revolution in Early Modern Europe (Cambridge: Cambridge University Press).

Elias, Norbert (1993-1994), Über den Prozeß der Zivilisation, 2 vols (Frankfurt/ Main: Suhrkamp).

Ellis, Aytoun (1956), The Penny Universities: A History of the Coffee-houses (London: Secker \& Warburg).

England and Wales, Parliament: A collection of some memorable and weighty transactions in Parliament in the year 1678 and afterwards in relations to the impeachment of Thomas, Earl of Danby (1695) (London).

Erickson, Amy (1993), Women and Property in Early Modern England (London and New York: Routledge).

Esposito, Elena (2004), Die Verbindlichkeit des Vorübergehenden: Paradoxien der Mode, trans. Allesandra Corti (Frankfurt/Main: Suhrkamp). 
Etherege, George (1982), The Plays of Sir George Etherege (Cambridge: Cambridge University Press).

An Examination of the Impartial State of the Case of the Earl of Danby in a Letter to a Member of the House of Commons (1680) (London).

Faller, Lincoln B. (1993), Crime and Defoe: A New Kind of Writing (Cambridge: Cambridge University Press).

Feldmann, Doris (1995), "The Modern "Art of Puffing": Theatrical and Political

Discourses in Richard Brinsley Sheridan's The Critic', QWERTY 5: 87-97.

[Fenn, Eleanor] (c. 1782), School Occurrences (London). (1784), The Female Guardian (London).

Fielding, Henry (1980, 1742 and 1741), 'Joseph Andrews' and 'Shamela', Douglas Brooks-Davies (ed.) (Oxford: Oxford University Press).

(1988, 1751), An Enquiry into the Causes of the Late Increase of Robbers,

Malvin R. Zirker (ed.) (Oxford: Clarendon Press). (2004), Plays. Volume I: 1728-1731 (Oxford: Clarendon Press). (2007), Histoire de Tom Jones, enfant trouvé, Michel Baridon (ed.) (Paris:

Gallimard).

Fielding, Sarah (1749), The Governess; or, Little Female Academy (London: A. Millar).

Fischer-Lichte, Erika (1990), Geschichte des Dramas: Epochen der Identität auf dem Theater von der Antike bis zur Gegenwart, 2 vols (Tübingen: Francke). (2004), Ästhetik des Performativen (Frankfurt/Main: Suhrkamp).

Fletcher, Loraine (2001), Charlotte Smith (Houndmills: Palgrave).

Fludernik, Monika (1996), Towards a 'Natural'Narratology (London: Routledge). Flynn, Carol Houlihan (1990), The Body in Swift and Defoe (Cambridge: Cambridge University Press).

Foote, Samuel (1974), The Works (repr. Hildesheim: Olms).

Foucault, Michel (1979), Discipline and Punish (New York: Vintage).

Fox, Christopher (1982), 'Locke and the Scriblerians: The Discussion of Identity in Early Eighteenth Century England', Eighteenth-Century Studies 16: 1-25.

Fraser, Nancy (1989), 'Rethinking the Public Sphere', in Calhoun, 109-42.

Freeman, Lisa (2002), Character's Theatre: Genre and Identity on the EighteenthCentury English Stage (Philadelphia: University of Pennsylvania Press).

Friedman, Lawrence M. (1975), The Legal System: A Social Perspective (New York: Russell Sage Foundation).

Frushell, Richard C. (1968), 'An Edition of the Afterpieces of Kitty Clive' (Diss. Duquesne University).

- (1970), "The Textual Relationship and Biographical Significance of Two Petite Pieces by Mrs. Catherine (Kitty) Clive', Restoration and 18th-Century Theatre Research 9.1 (May): 51-8.

Garside, Peter, James Raven, and Rainer Schöwerling (eds) (2001), The English Novel 1770-1829: A Bibliographical Survey of Prose Fiction Published in the British Isles, 2 vols (Oxford: Oxford University Press). 
Genette, Gérard (1997), Paratexts: Thresholds of Interpretation, trans. Jane E. Lewin (Cambridge: Cambridge University Press).

Godwin, William (1982, 1794), Caleb Williams, David McCracken (ed.) (Oxford: Oxford University Press).

- $(1993,1831)$, 'Thoughts On Man, His Nature, Productions and Discoveries. Interspersed with Some Particulars Respecting the Author', in Mark Philp (ed.), Political and Philosophical Writings of William Godwin; vol. VI: Essays (London: William Pickering), 31-292.

- (2001, 1805), Fleetwood: or, The New Man of Feeling, Gary Handwerk and A.A. Markley (eds) (Peterborough: Broadview).

Goulemont, Jean Marie (1994), Forbidden Texts: Erotic Literature and its Readers in Eighteenth-Century France, trans. James Simpson (Cambridge: Polity).

Greaves, Richard L. (1990), Enemies under His Feet: Radicals and Nonconformists in Britain, 1664-1677 (Stanford: Stanford University Press).

Green, Thomas Andrew (1985), Verdict According to Conscience: Perspectives on English Criminal Trial Jury, 1200-1800 (Chicago: University of Chicago Press).

Greenblatt, Stephen (1980), Renaissance Self-Fashioning: From More to Shakespeare (Chicago: University of Chicago Press).

Greene, John C. and Gladys L.H. Clark (1993), The Dublin Stage, 1720-1745: A Calendar of Plays, Entertainments, and Afterpieces (Bethlehem: Lehigh University Press).

Gregg, Stephen (1999), 'Godly Manliness: Defoe's Men in Bad Times', in Andrew P. Williams (ed.), The Image of Manhood in Early Modern Literature: Viewing the Male (Westport, CT: Greenwood), 141-59.

- (2009), Defoe's Writings and Manliness: Contrary Men (Farnham: Ashgate).

Gregory, Jeremy (1997), 'Homo Religiosus: Masculinity and Religion in the Long Eighteenth Century', in Hannah Barker and Elaine Chalus (eds), Gender in Eighteenth Century England: Roles, Representations and Responsibilities (London: Longman), 85-111.

Grenby, Matthew O. (2002), 'Adults Only? Children and Children's Books in British Circulating Libraries, 1748-1848', Book History 5: 19-38.

Habermas, Jürgen (1962), Strukturwandel der Öffentlichkeit: Untersuchungen zu einer Kategorie der bürgerlichen Gesellschaft (Neuwied: Luchterhand).

- (1974, 1964), 'The Public Sphere: An Encyclopedia Article', trans. Sara and Frank Lennox, New German Critique 3: 49-55.

- (1989), The Structural Transformation of the Public Sphere, trans. Thomas Burger (Cambridge: Polity Press).

Hall, Stuart (1979), "Culture, the Media and the "Ideological Effect"', in James Curran (ed.), Mass Communication and Society (London: Edward Arnold), 315-48.

(2000), 'Who needs 'identity'?', in Paul Du Gay, Jessica Evans, and Peter Redman (eds), Identity: A Reader (London: Sage), 15-30. 
(2005), 'Thinking the Diaspora: Home-thoughts from Abroad', in Gaurav Desai and Supriya Nair (eds), Postcolonialisms: An Anthology of Cultural Theory (New Brunswick: Rutgers University Press), 543-60.

Hammond, Brean S. (1997), Professional Imaginative Writing in England 16701740: Hackney for Bread (Oxford: Clarendon Press).

The Harcourt Papers (1880-1905), E.W. Harcourt (ed.) (13 vols, Oxford: Parker). Hargrave, Francis (ed.) (1777), A Complete Collection of State-Trials, and Proceedings for High-Treason, And other Crimes and Misdemeanors, vol. 5, 4th edn (London: T. Wright), 339 83.

Harlow, Barbara and Mia Carter, (eds) (1999), Imperialism and Orientalism: $A$ Documentary Sourcebook (Oxford: Blackwell).

Harris, Michael (1986), 'Introduction: The Seventeenth and Eighteenth Centuries', in Michael Harris and Alan Lee (eds), The Press in English Society from the Seventeenth to Nineteenth Centuries (London: Associated University Press), 19-24.

Harris, Susan Cannon (2007), 'Mixed Marriage: Sheridan, Macklin, and the Hybrid Audience', in Michael Cordner and Peter Holland (eds), Players, Playwrights, Playhouses: Investigating Performance, 1660-1800 (Basingstoke: Palgrave), $189-212$.

Harris, Tim (2001), 'Understanding Popular Politics in Restoration Britain', in Alan Houston and Steve Pincus (eds), A Nation Transformed: England After the Restoration (Cambridge: Cambridge University Press), 125-53.

Harvey, Karen (2004), Reading Sex in the 18th Century: Bodies and Gender in English Erotic Culture (Cambridge: Cambridge University Press).

Haywood, Eliza (2000, 1719/1729), Love in Excess; or, The Fatal Inquiry, David Oakleaf (ed.), 2nd edn (Peterborough: Broadview).

Helmstetter, Rudolf (2007), 'Der Geschmack der Gesellschaft: Die Massenmedien als Apriori des Populären', in Christian Huck and Carsten Zorn (eds), Das Populäre der Gesellschaft: Systemtheorie und Populärkultur (Wiesbaden: VSVerlag), 44-72.

Hentzi, Gary (1993), 'Sublime Moments and Social Authority in Robinson Crusoe and A Journal of the Plague Year', Eighteenth-Century Studies 26.3: 419-34.

Herrup, Cynthia B. (1985), 'Law and Morality in Seventeenth-Century England', Past and Present 106: 102-23.

Heyl, Christoph (2004), A Passion for Privacy: Untersuchungen zur Genese der bürgerlichen Privatsphäre in London, 1660-1800 (Munich: Oldenbourg).

Heywood, Colin (2001), A History of Childhood (Cambridge: Polity).

Hillis Miller, J. (1992), Illustration (London: Reaktion Books).

The History of Little Goody Two-Shoes; Otherwise called, Mrs. Margery TwoShoes (1766) (London).

Hoadly, Benjamin (1710), An Explanation of some Hard Terms now in Use: For the Information of all such as Read, or Subscribe Addresses (London).

Hogarth, William (1955), The Analysis of Beauty, Joseph Burke (ed.) (Oxford: Clarendon). 
Holmes, Geoffrey (1993), The Making of a Great Power: Late Stuart and Early Georgian Britain 1660-1722 (London: Longman).

Hoppit, Julian (2000), A Land of Liberty? England 1689-1727 (Oxford: Oxford University Press).

Horle, Craig (1988), The Quakers and the English Legal System 1660-1688 (Philadelphia: University of Philadelphia Press).

Houswitschka, Christoph (1997), “ "...] where Culture spreads luxuriant" - John Thelwall's Poetical Relocation of Burkean Values', in Jürgen Kamm (ed.), The City and the Country: Proceedings from the Sixth British and Cultural Studies Conference Dresden 1995 (Essen: Die Blaue Eule), 31-50. -(ed.) (2004), Freedom - Treason-Revolution: Uncollected Sources of the Political and Legal Culture of the London Treason Trials (1794) (Frankfurt/ Main: Lang).

Huck, Christian (2007), 'Calico Bill and the Calico Madams: Fashion, Print, and the Public', in Sabine Volk-Birke and Julia Lippert (eds), Anglistentag 2006 Halle: Proceedings (Trier: WVT), 53-63.

(2010), Fashioning Society, or, the Mode of Modernity: Observing Fashion in Eighteenth-Century Britain (Würzburg: Königshausen \& Neumann).

Hyde, Ralph (1988), Panoramania! The Art and Entertainment of the 'AllEmbracing' View (London: Trefoil \& Barbican Art Gallery).

Immel, Andrea and Michael Witmore (eds) (2006), Childhood and Children's Books in Early Modern Europe, 1550-1800 (London: Routledge).

An Impartial State of the Case of the Earl of Danby in a Letter to a Member of the House of Commons (1679) (London).

Innes, Ionna (1990), 'Politics and Morals: The Reformation Manners Movement in Later Eighteenth-Century England', in Eckhardt Hellmuth (ed.), The Transformation of Political Culture: England and Germany in the late 18th Century (Oxford: Oxford University Press), 57-118.

Isaacs, Tina (1982), 'The Anglican Hierarchy and the Reformation of Manners 1688-1738', Journal of Ecclesiastical History 33: 391-411.

Iser, Wolfgang (1994a), Der implizite Leser: Kommunikationsformen des Romans von Bunyan bis Beckett, 3rd edn (Munich: Fink).

- (1994b), Der Akt des Lesens: Theorie ästhetischer Wirkung, 4th edn (Munich: Fink).

Jackson, Mary V. (1989), Engines of Instruction, Mischief, and Magic: Children's Literature in England from its Beginnings to 1839 (Lincoln: University of Nebraska Press).

James, Lawrence (1998), The Rise and Fall of the British Empire (London: Abacus). Janeway, James (1763), A Token for Children: Being An Exact Account of the Conversion, Holy and Exemplary Lives and Joyful Deaths of several Young Children. In Two Parts (London).

Jarvis, Robin (1997), Romantic Writing and Pedestrian Travel (New York: St. Martin's Press). 
Jasanoff, Maya (2005), Edge of Empire: Conquest and Collecting in the East, 1750-1850 (London: Fourth Estate).

Jefferies, J. (1750), The Virtuous Novelist; or, Little Polite Court Tales; Compos'd Originally for the Education of a Young French Prince; by the Universally admir'd Author of Telemachus with other Ingenious Fictions \&c. Abridg'd for the Amusement \& Instruction of our British Youth of Both Sexes (London).

Joncus, Berta (2005), "His Spirit is in Action Seen": Milton, Mrs. Clive and the Simulacra of the Pastoral in Comus', Eighteenth-Century Music 2.1: 7-40.

Jones, Robert W. (2002), 'Sheridan and the Theatre of Patriotism: Staging Dissent During the War for America', Eighteenth-Century Life 26.1:24-45.

-Juengel, Scott (1995), 'Writing Decomposition: Defoe and the Corpse', Journal of Narrative Technique 25: 139-53.

Kames, Henry Home Lord (1774-1775), Sketches of the History of Man. In four volumes, vol. I (Dublin), Eighteenth Century Collections Online, Gale Group, http://galenet.galegroup. com/servlet/ECCO (1.12.2007).

Karremann, Isabel (2008), Männlichkeit und Körper: Inszenierungen eines geschlechts-spezifischen Unbehagens im englischen Roman des 18. und frühen 19. Jahrhunderts (Königstein: Taunus).

Kelley, Hugh (1766), Thespis, or, a critical examination into the Merits of All the Principal Performers Belonging to Drury-Lane Theatre (London).

Keupp, Heiner (ed.) (1993), Zugänge zum Subjekt: Perspektiven einer reflexiven Sozialpsychologie (Frankfurt/Main: Suhrkamp).

- (ed.) (2002), Identitätskonstruktionen: Das Patchwork der Identitäten in der Spätmoderne, 2nd edn (Reinbek: Rowohlt).

Keymer, Thomas and Peter Sabor (eds) (2001), The Pamela Controversy: Criticisms and Adaptations of Samuel Richardson's Pamela, 1740-1750, 6 vols (London: Pickering \& Chatto).

Kibbie, Anne Louise (1991), 'Sentimental Properties: Apela and Memoirs of a Woman of Pleasure', ELH 58: 561-77.

[Kilner, Mary Ann] (c. 1785), The Adventures of a Whipping-Top (London).

King, Kathryn R. (1995), 'Of Needles and Pens and Women's Work', Tulsa Studies in Women's Literature 14.1: 77-93.

King, Ross (1993), 'Wordsworth, Panoramas, and the Prospect of London', Studies in Romanticism 32: 57-73.

King, Thomas A. (2004), The Gendering of Men, 1600-1750, 2 vols (Madison: University of Wisconsin Press).

Kinservik, Matthew J. (1996), 'Garrick's Unpublished Epilogue for Catherine Clive's The Rehearsal: or, Bays in Petticoats (1750)', Etudes Anglaises 49.3: 320-26.

Knights, Mark (2005), 'History and Literature in the Age of Defoe and Swift', History Compass 3: 1-20.

Knowles, Murray and Kirsten Malmkjaer (1996), Language and Control in Children's Literature (New York: Routledge). 
Knox, John (1988, 1810), South-western view from Loch Lomond and Southwestern view from Ben Lomond, in Hyde, 40.

Koschorke, Albrecht (1999), Körperströme und Schriftverkehr: Mediologie des 18. Jahrhunderts (Munich: Fink).

Kubek, Elizabeth (2003), "The Man Machine: Horror and the Phallus in Memoirs of a Woman of Pleasure', in Patsy S. Fowler and Alan Jackson (eds), Launching Fanny Hill: Essays on the Novel and Its Influences (New York: AMS Press), 173-95.

Lacan, Jacques (1993), The Seminar. Book III. The Psychoses, 1955-56, trans. Russell Grigg (London: Routledge).

Lamb, Mary and Charles Lamb (1995, 1809), Mrs Leicester's School (Poole: Woodstock Books).

Lamoine, George (ed.) (1992), Charges to the Grand Jury 1689-1803 (London: Royal Historical Society).

Landes, Joan (ed.) (1998), Feminism, the Public and the Private (Oxford: Oxford University Press).

Langan, Celeste (1995), Romantic Vagrancy: Wordsworth and the Simulation of Freedom (Cambridge: Cambridge University Press).

Laqueur, Thomas (1990), Making Sex: Body and Gender from the Greeks to Freud (Cambridge: Harvard University Press).

Lauster, Martina (2007), 'Walter Benjamin's Myth of the Flaneur', The Modern Language Review 102.1: 139-56.

Leask, Nigel (2004), Curiosity and the Aesthetics of Travel Writing, 1770-1840 (Oxford: Oxford University Press).

Leavy, Barbara Fass (1992), 'The Historical and Ethical Significance of Defoe's Journal of the Plague Year', in Barbara Fass Leavy, To Blight with Plague: Studies in a Literary Theme (New York: New York University Press), 21-39.

Leeds, Thomas Osborne, Duke of; Tewksbury, Henry Capel, Lord Capel of (1678), Articles of impeachment of high treason and other hih [sic] crimes, misdemeanours and offences against Thomas, Earl of Danby, Lord High Treasurer of England as they were delivered in to the House of Lords in the name of the Commons of England, by Sir Henry Capel, December 23, 1678, together with a letter of the lord treasurers to Mr. Montague, late embassador in France (London).

Lesnik-Oberstein, Karín (1999), 'Essentials: What is Children's Literature? What is Childhood?', in Peter Hunt (ed.), Understanding Children's Literature: Key Essays from the International Companion Encyclopedia of Children's Literature (London: Routledge), 15-29.

Leujeune, Philippe (1975), Le pacte autobiographique (Paris: Seuil).

The Life of Mr. James Quin, Comedian. With the History of the Stage from his Commencing Actor to his Retreat to Bath (1766) (London).

Lillo, George (1965, 1731), The London Merchant (London: Arnold).

Lillywhite, Bryant (1963), London Coffee-Houses: A Reference Book of CoffeeHouses of the 17th and 18th centuries (London: Allen \& Unwin). 
Linebaugh, Peter (1992), The London Hanged: Crime and Society in the Eighteenth Century (Cambridge: Cambridge University Press).

Lipovetsky, Gilles (1994), The Empire of Fashion: Dressing Modern Democracy, trans. C. Porter (Princeton: Princeton University Press).

Little Master's Miscellany. Or Divine and Moral Essays, in Prose and Verse, Adapted to the Capacities and Deign'd for the Improvement of the Youth of both Sexes (1748), 2nd edn (Birmingham).

Lloyd, David (1990), Ireland After History (Cork: Cork University Press).

Lloyd, Geneviève (1984), The Man of Reason: 'Male' and 'Female' in Western Philosophy (London: Methuen).

Locke, John (1988, 1689), Two Treatises of Government, Peter Laslett (ed.) (Cambridge: Cambridge University Press).

(2000, 1693), Some Thoughts Concerning Education, John W. and Jean S. Yolton (eds) (Oxford: Clarendon).

Lord, Edward (1724), A Sermon Preached to the Societies for Reformation of Manners [...] The Thirtieth Account of the Progress made in the Cities of London and Westminster, and Places adjacent, By the Societies for the Promoting a Reformation of Manners; By Furthering the Execution of Laws against Prophaneness and Immorality, and other Christian Methods (London).

Love, Harold (1993), Scribal Publication in Seventeenth-Century England (Oxford: Oxford University Press).

Löw, Martina (2007), Raumsoziologie, 5th edn (Frankfurt/Main: Suhrkamp).

Ludden, David (2008), 'Orientalist Empiricism: Transformations of Colonial Knowledge', in Edmund Burke III and David Prochaska (eds), Genealogies of Orientalism. History, Theory, Politics (Lincoln and London: University of Nebraska Press), 75-101.

Luhmann, Niklas (1989), 'Individuum, Individualität, Individualismus', Gesellschaftsstruktur und Semantik: Studien zur Wissenssoziologie der modernen Gesellschaft, vol. 3 (Frankfurt/Main: Suhrkamp), 149-258.

- (1990), 'Gesellschaftliche Komplexität und öffentliche Meinung', Soziologische Aufklärung, vol. 5 (Opladen: Westdeutscher Verlag), 170-82.

(1997), Die Gesellschaft der Gesellschaft, 2 vols (Frankfurt/Main: Suhrkamp).

- (1998), Gesellschaftsstruktur und Semantik, 5 vols (Frankfurt/Main: Suhrkamp).

- (2000), The Reality of the Mass Media, trans. Kathleen Cross (Stanford: Stanford University Press).

- (2004), Die Realität der Massenmedien, 3rd edn (Wiesbaden: VS Verlag).

Macfie, A.L. (2002), Orientalism (London: Longman).

MacKenzie, John (1996). 'Art and the Empire', in Peter James Marshall (ed.), The Cambridge Illustrated History of the British Empire (Cambridge: Cambridge University Press), 296-317.

Mackie, Erin (1997), Market à la Mode: Fashion, Commodity, and Gender in The Tatler and The Spectator (Baltimore, London: Johns Hopkins University Press). 
Maclean, Marie (1991), 'Pretexts and Paratexts: The Art of the Peripheral', New Literary History 22: 273-9.

Maese, Sarah (1766), The School (London).

Mainwaring, Arthur (1975, 1711), 'An Excellent New Song, Called Mat's Peace, Or, The Downfall of Trade', in F.H. Ellis (ed.), Poems on Affairs of State, vol. 7 (New Haven, CT: Yale University Press), 504-13.

Makdisi, Saree (1998), Romantic Imperialism: Universal Empire and the Culture of Modernity (Cambridge: Cambridge University Press).

Malcolmson, Robert W. (1973), Popular Recreations in English Society 1700 1850 (Cambridge: Cambridge University Press).

Marshall, J.P. (1993), Trade and Conquest: Studies on the Rise of British Dominance in India (Aldershot: Variorum).

Maus, Katharine Eisaman (1995), Inwardness and Theater in the English Renaissance (Chicago: Chicago University Press).

Mayer, Robert (1990), 'The Reception of A Journal of the Plague Year and the Nexus of Fiction and History in the Novel', ELH 57.3: 529-55.

McDowell, Paula (1998), The Women of Grub Street: Press, Politics, and Gender in the London Literary Marketplace 1678-1730 (Oxford: Clarendon Press).

- (2006), 'Defoe and the Contagion of the Oral: Modeling Media Shift in A Journal of the Plague Year', PMLA 121.1: 87-106.

McLane, Maureen (2001), 'Ballads and Bards: British Romantic Orality,' Modern Philology 98.3: 423-43.

McLynn, Frank (1989), Crime and Punishment in Eighteenth-century England (London: Routledge).

Meehan, Johanna (ed.) (1995), Feminists Read Habermas: Gendering the Subject of Discourse (New York, London: Routledge).

Meißner, Karin (1994), Au Lecteur: Studien zu den französischen Romanvorworten des 17. Jahrhunderts (Frankfurt/Main: Lang).

Mellor, Anne K. (2000), Mothers of the Nation: Women's Political Writing in England 1780-1830 (Bloomington: Indiana University Press).

Melton, James van Horn (2001), The Rise of the Public in Enlightenment Europe (Cambridge: Cambridge University Press).

Memoirs of the Extraordinary Life, Works, and Discoveries of Martinus Scriblerus. Written in Collaboration with the Members of the Scriblerus Club (1988), Charles Kerby-Miller (ed.) (New York: Oxford University Press).

Miège, Guy (1703), The New State of England, Under Our Sovereign, Queen Anne, in three parts, 5 th ed. (London).

Miller, Louise M. (1995), 'Invasion as Theatrical Appropriation in The Critic', QWERTY 5: 99-104.

Milne, Anne (2008), 'Lactilla Tends Her Fav'rite Cow': Ecocritical Readings of Animals and Women in Eighteenth-Century British Labouring-Class Women's Poetry (Lewisburg, PA: Bucknell University Press).

Mirzoeff, Nicholas (ed.) (1998), The Visual Culture Reader (Routledge: New York). 
Mitchell, W.J.T. (2002), Landscape and Power, 2nd edn (Chicago: Chicago University Press).

Montaigne, Michel de (2006), Essays, Book I, trans. John Floriot, 3 vols (London: The Folio Society).

Moore, Benjamin (1992), 'Governing Discourses: Problems of Narrative Authority in A Journal of the Plague Year', The Eighteenth Century: Theory and Interpretation 33.2: 133-47.

Moore, Lisa (1997), Dangerous Intimacies: Toward a Sapphic History of the British Novel (Durham: Duke University Press).

Morash, Christopher (2002), A History of Irish Theatre 1601-2000 (Cambridge: Cambridge University Press).

Moritz, Karl Philipp (2000), Reisen eines Deutschen in England im Jahre 1782 (Frankfurt/Main: Insel).

Morley, David (1992), Television, Audiences and Cultural Studies (London: Routledge).

Muir, Percy (1954), English Children's Books, 1600 to 1900 (London: B.T. Batsford).

Müllenbrock, Heinz-Joachim (1997), The Culture of Contention: A Rhetorical Analysis of the Public Controversy About the Ending of the War of the Spanish Succession, 1710-1713 (Munich: Fink).

Müller, Anja (2006), 'Spectatorship and Performance in Eighteenth-Century Periodicals', in Frédéric Ogée and Peter Wagner (eds), Representation and Performance in the Eighteenth Century (Trier: WVT), 191-207.

- (2009), Framing Childhood in Eighteenth-Century English Periodicals and Prints, 1689-1789 (Aldershot: Ashgate).

Mulvey, Laura (1975), 'Visual Pleasure and Narrative Cinema', Screen 16.3: 6-18; repr. in Leo Braudy and Marshall Cohen (eds) (1999), Film Theory and Criticism: Introductory Readings (Oxford: Oxford University Press), 833-44.

Naumann, Peter (1976), Keyhole and Candle: John Cleland's "Memoirs of a Woman of Pleasure" und die Entstehung des pornographischen Romans in England (Heidelberg: Winter).

Nenner, Howard (1995), The Right to be King: The Succession to the Crown of England, 1603-1714 (Basingstoke: Macmillan).

Neumann, Fritz Wilhelm (2008), 'Spying the Innumerable Attractions and Distractions of the Metropolis: The London Leisure Industry in the Early Eighteenth Century', EESE 3, http://webdoc.gwdg.de/edoc/ia/eese/eese.html.

Newman, Donald J. (2005), 'Introduction', in Donald J. Newman (ed.), The Spectator: Emerging Discourses (Newark: University of Delaware Press), 11-38.

Nicholson, Marjorie Hope (1976), Science and Imagination (Hamden, CT: Archon Books).

Nixon, Cheryl L. (2002), "Stop a Moment at this Preface": The Gendered Paratexts of Fielding, Barker and Haywood', JNT: Journal of Narrative Theory 32.2: $123-53$. 
Nodelman, Perry (2000), 'Pleasure and Genre: Speculations on the Characteristics of Children's Fiction', Children's Literature 28: 1-14.

Novak, Maximilian E. (1977), 'Introduction', in Maximilian E. Novak (ed.), English Literature in the Age of Disguise (Berkeley, CA: Yale University Press), 1-14.

- (1992), 'Defoe and the Disordered City', in Paula R. Backscheider (ed.), Daniel Defoe: A Journal of the Plague Year (New York: Norton), 301-18.

Nussbaum, Felicity (2003), The Limits of the Human: Fictions of Anomaly, Race, and Gender in the Long Eighteenth Century (Cambridge: Cambridge University Press).

- (2006), "Naughty Pamela's "Sweet Confusion", in Lisa Zunshine and Jocelyn Harris (eds), Approaches to Teaching the Novels of Samuel Richardson. (New York: Modern Language Association of America), 63-9.

O'Brien, John (2005), 'Genre, Gender, Theater', in Cynthia Wall (ed.), A Concise Companion to the Restoration and Eighteenth Century (London: Blackwell), 183-201.

O'Connell, Michael (2000), The Idolatrous Eye: Iconoclasm and Theatre in Early Modern England (Oxford: Oxford University Press).

O'Malley, Andrew (2003), The Making of the Modern Child: Children's Literature and Childhood in the Late Eighteenth Century (New York: Routledge).

O'Toole, Fintan (1997), A Traitor's Kiss: The Life of Richard Brinsley Sheridan (London: Granta).

Oettermann, Stephan (1980), Das Panorama: Die Geschichte eines Massenmediums (Frankfurt/Main: Syndikat).

Ogden, Daryl (2005), The Language of the Eyes: Science, Sexuality, and Female Vision in English Literature and Culture, 1690-1927 (Albany, NY: SUNY).

Old Bailey Proceedings Online (2003-2008), http://www.oldbaileyonline.org/ (5 December 2008).

Ong, Walter J. (2002), Orality and Literacy: The Technologizing of the Word (London: Routledge).

Orme, Nicholas (2001), Medieval Children (New Haven: Yale University Press). Outhwaite, Richard B. (2006), The Rise and Fall of the English Ecclesiastical Courts, 1500-1860 (Cambridge: Cambridge University Press).

Owen, Susan J. (1996), Restoration Theatre and Crisis (Oxford: Clarendon).

Pateman, Carole (1988), The Sexual Contract (Cambridge: Polity).

Paulson, Ronald (1989), Hogarth's Graphic Works (London: The Print Room). (1991), Hogarth, vol. I: The 'Modern Moral Subject' (New Brunswick: Rutgers University Press).

- (1992), Hogarth, vol. II: 'High Art and Low' (New Brunswick: Rutgers University Press).

Peakman, Julie (2003), Mighty Lewd Books: The Development of Pornography in Eighteenth-Century England (New York: Macmillan). 
[Penn, William] (1670), The Peoples Ancient and Just Liberties asserted, in the Tryal of William Penn, and William Mead, at the Sessions held at the OldBailey in London, the first, third, fourth and fifth of Sept. 1670. against the most Arbitrary Procedure of that Court, repr. in Phenix XI (1670?), in British Trials $1660-1900$, no. $4(10 / 1)$ and no. 5.

Penn, William (1794), The People's Ancient and Just Liberties Asserted [...] (Sheffield).

Pfau, Thomas (1997), 'Paranoia Historicized: Legal Fantasy, Social Change, and Satiric Meta-Commentary in the 1794 Treason Trials', in Stephen C. Behrendt (ed.), Romanticism, Radicalism, and the Press (Detroit: Wayne State University Press), 30-64.

Phillips, Nicola (2006), Women in Business, 1700 -1850 (Woodbridge, Suffolk: Boydell Press).

Pincus, Stephen (1995), "Coffee, Politicians Does Create": Coffeehouses and Restoration Political Culture', Journal of Modern History 67: 807-34.

Plotz, John (2000), The Crowd: British Literature and Public Politics (Berkeley: University of California Press).

Plumb, J.H. (1982), 'The Commercialization of Leisure', in Neil McKendrick, John Brewer, and J.H. Plumb (eds), The Birth of a Consumer Society (Bloomington: Indiana University Press).

Pocock, J.G.A. (1975), The Machiavellian Moment: Florentine Political Thought and the Atlantic Republican Tradition (Princeton: Princeton University Press).

- (1985), Virtue, Commerce, and History: Essays on Political Thought, Chiefly in the Eighteenth Century (New York: Cambridge University Press).

Pollock, Linda (1983), Forgotten Children: Parent -Child Relations from 1500 to 1900 (Cambridge: Cambridge University Press).

Porter, Robert Ker and John Vendramini (1800), The Storming of Seringapatam, in Hyde, 65.

Porter, Roy (1982), 'Mixed Feelings: The Enlightenment and Sexuality in Eighteenth-Century Britain', in Paul-Gabriel Bouce (ed.), Sexuality in Eighteenth-Century Britain (Manchester: Manchester University Press), 1-27.

Pratt, Mary Louise (1992), Imperial Eyes: Studies in Travel Writing and Transculturation (London: Routledge).

Ragussis, Michael (2000), "Jews and Other "Outlandish Englishmen": Ethnic Performance and the Invention of British Identity under the Georges', Critical Inquiry 26 (Summer): 773-97.

Rambuss, Richard (1989), "A Complicated Distress": Narrativizing the Plague in Defoe's A Journal of the Plague Year', Prose Studies 12: 115-31.

Raymond, Joad (2003), Pamphlets and Pamphleteering in Early Modern Britain (Cambridge: Cambridge University Press).

Reinfandt, Christoph (1997), Der Sinn der fiktionalen Wirklichkeiten: Ein systemtheoretischer Entwurf zur Ausdifferenzierung des englischen Romans vom I8. Jahrhundert bis zur Gegenwart (Heidelberg: Winter). 
Rennhak, Katharina and Virginia Richter (2004), 'Einleitung', in Katharina Rennhak and Virginia Richter (eds), Revolution und Emanzipation (Cologne: Böhlau Verlag), 5-13.

The Renowned History of Primrose Prettyface, who By her Sweetness of Temper and Love of Learning, was raised from being the Daughter of a poor Cottager, to great Riches, and the Dignity of Lady of the Manor (1782) (London, n.d.).

Richards, Sandra (1993), The Rise of the English Actress (London: St. Martin's Press). Richardson, Jonathan $(1725,1715)$, Essay on the Theory of Painting (London: Bettesworth).

- (1856), Recollections, Political, Literary, Dramatic and Miscellaneous of the Last Half-Century (London: C. Mitchell).

Richardson, Samuel (1980, 1740), Pamela; or, Virtue Rewarded, Peter Sabor (ed.) (London: Penguin).

- $(1986,1753)$, Sir Charles Grandison, Jocelyn Harris (ed.) (Oxford: Oxford University Press).

- (2004, 1747), Clarissa; or, The History of a Young Lady, Angus Ross (ed.) (London: Penguin).

Richetti, John (1992), 'Epilogue: A Journal of the Plague Year as Epitome', in Paula R. Backscheider (ed.), Daniel Defoe: A Journal of the Plague Year (New York: Norton), 295-301.

Ricoeur, Paul (1991), 'Narrative Identity', Philosophy Today 35.1: 73-81.

- (1992), Oneself as Another (Chicago: Chicago University Press).

Roach, Joseph (2003), 'Celebrity Erotics: Pepys, Performance, and Painted Ladies', Yale Journal of Criticism 16.1:211-30. (2007), It (Ann Arbor: University of Michigan Press).

Ronksley, William (1712), The Child's Weeks-work: or, A Little Book, so nicely Suited to the Genius and Capacity of a Little Child, Both for Matter and Method, That it will infallibly Allure and Lead him on into a Way of Reading With all the Ease and Expedition that can be desired (London).

Rosenthal, Laura (2006), Infamous Commerce: Prostitution in Eighteenth-Century British Literature and Culture (Ithaca: Cornell University Press).

Rousseau, George S. (1968), 'Nerves, Spirits, and Fibres: Towards Defining the Origins of Sensibility', in Studies in the Eighteenth Century: Papers Presented at the David Nichol Smith Memorial Seminar, Canberra, 1966 (Toronto: University of Toronto Press), 137-57.

Said, Edward (1994), Orientalism (New York: Vintage Books).

Schabert, Ina (1997), Englische Literaturgeschichte: Eine neue Darstellung aus der Sicht der Geschlechterforschung (Stuttgart: Kröner).

Schindler, Stephan K. (1996), 'The Critic as Pornographer: Male Fantasies of Female Reading in Eighteenth-Century Germany', Eighteenth-Century Life 20.3: 66-80.

Schmitz, Thomas A. (2000), 'Plausibility in the Greek Orators', American Journal of Philology 121: 47-77. 
Schoenfeldt, Michael C. (1999), Bodies and Selves in Early Modern England: Physiology and Inwardness in Spenser, Shakespeare, Herbert, and Milton (Cambridge: Cambridge University Press).

Scholz, Susanne (2000), Body Narratives: Writing the Nation and Fashioning the Subject in Early Modern England (Houndmills: Macmillan).

Schröder, Hans-Christoph (2006), 'Die Geschichte Englands bis 1945', in Hans

Kastendiek and Roland Sturm (eds), Länderbericht Großbritannien (Bonn: Budrich), 14-51.

Schroer, Markus (2006), Räume, Orte, Grenzen: Auf dem Weg zu einer Soziologie des Raums (Frankfurt/Main: Suhrkamp).

Schulte-Sasse, Jochen (1990), 'Aesthetic Illusion in the Eighteenth Century', in Frederick Burwick and Walter Pape (eds), Aesthetic Illusion: Theoretical and Historical Approaches (Berlin: De Gruyter), 105-21.

Scrivener, Michael Henry (2001), Seditious Allegories: John Thelwall and Jacobin Writing (University Park: Penn State University Press).

Sehsucht: Das Panorama als Massenunterhaltung des 19. Jahrhunderts (1993), Kunst- und Ausstellungshalle der BRD (ed.) (Frankfurt/Main: Stroemfeld).

Seigel, Jerrold (2005), The Idea of the Self: Thought and Experience in Western Europe since the Seventeenth Century (Cambridge: Cambridge University Press). Sen, Sudipta (2004), 'Liberal Government and Illiberal Trade: the Political Economy of "Responsible Government" in Early British India', in Kathleen Wilson (ed.), A New Imperial History. Culture, Identity, and Modernity in Britain and the Empire, 1660-1840 (Cambridge: Cambridge University Press), 136-54.

Shaftesbury, Anthony Ashley Cooper (1900, 1711), Characteristics of Men, Opinions, Times, John M. Robertson (ed.), 2 vols (London: Richards).

Shavit, Zohar (1990), 'Cultural Notions and Literary Boundaries: On the

Creation of the Systemic Opposition between Children's Literature and Adult Literature in the Eighteenth Century', Proceedings of the XIIth Congress of the International Comparative Literature Society (Munich: Iudicum), 416-22. Sheik Ali, B. (1999), 'French Relations with Haidar Ali and Tipu Sultan', in K.S. Mathew and S. Jeyaseela Stephen (eds), Indo-French Relations (Delhi: Pragati Publications).

Sheridan, Richard Brinsley $(1979,1777)$, The School for Scandal (London: A \& C Black). (1989, 1779), The Critic (London: A \& C Black).

Shoemaker, Robert B. (1998), Gender in English Society, 1650-1850 (London: Longman).

Shuger, Debora (2000), 'Life Writing in Seventeenth-Century England', in Patrick Coleman, Jayne Lewis, and Jill Kowalik (eds), Representations of the Self from the Renaissance to Romanticism (Cambridge: Cambridge University Press), 63-78.

Smith, Charlotte (1794), The Banished Man: A Novel, 4 vols (London: T. Cadell, Jr., and W. Davies). 
(1796), Marchmont: A Novel, 4 vols (London: Sampson Low).

(1993, 1792), 'Preface to the Sixth Edition [of Elegiac Sonnets and Other

Poems]', in Stuart Curran (ed.), The Poems of Charlotte Smith (New York:

Oxford University Press), 4-6.

- $(1997,1792)$, Desmond, Antje Blank and Janet Todd (eds) (London:

Pickering \& Chatto).

- (1999, 1798), The Young Philosopher, Elizabeth Kraft (ed.) (Lexington:

University Press of Kentucky).

Solkin, David H. (1982), Richard Wilson: The Landscape of Reaction (London:

The Tate Gallery).

Sommerville, C. John (1972), 'Bibliographic Note: Toward a History of Childhood and Youth', Journal of Interdisciplinary History 3.2: 439-47.

- (1972), The Discovery of Childhood in Puritan England (Athens: University of Georgia Press).

- (1981), 'Breaking the Icon: The First Real Children in English Books', History of Education Quarterly 21.1: 51-75.

- (1989), 'Puritan Humor, or Entertainment, for Children', Albion: A Quarterly Journal Concerned with British Studies 21.2: 227-47.

Speck, W.A. (1970), Tory \& Whig: The Struggle in the Constituencies, 1701-1715

(London: Macmillan).

(1994), The Birth of Britain: A New Nation 1700-1710 (Oxford: Blackwell).

Stafford, Barbara Maria (1984), Voyage into Substance: Art, Science, Nature, and the Illustrated Travel Account, 1760-1840 (Cambridge, MA: MIT Press).

Stallybrass, Peter and Allon White (eds) (1986), The Politics and Poetics of Transgression (Ithaca: Cornell University Press).

Stanton, Judith Phillips (1988), 'Statistical Profile of Women Writing in English from 1660 to 1800', in Frederick M. Keener and Susan Lorsch (eds), Eighteenth-Century Women and the Arts (New York: Greenwood), 247-54.

S[tarling], [Sir] S[amuel] (1671), An Answer To the Seditious and Scandalous

Pamphlet, Entituled, The Tryal of W. Penn and $W$. Mead, at the Sessions held at the Old Baily, London, the 1, 3, 4, 5 of Sept., 1670 [...] (London).

Starr, G. Gabrielle (2004), 'Objects, Imaginings, and Facts: Going beyond Genre in Behn and Defoe', Eighteenth-Century Fiction 16.4: 499-518.

Staves, Susan (1990), Married Women's Separate Property in England, 16601833 (Cambridge, MA: Harvard University Press).

Steel, David (1981), 'Plague Writing: From Boccaccio to Camus', Journal of European Studies 11: 88-110.

Steele, Richard (1987, 1709-1711), The Tatler, Donald Bond (ed.), 3 vols (Oxford: Clarendon). (1968, 1722), The Conscious Lovers (London: Arnold, 1968).

Steffen, Lisa (2001), Defining a British State: Treason and National Identity (Basingstoke: Palgrave). 
Stevenson, Nick (2003), Cultural Citizenship: Cosmopolitan Questions (Maidenhead: Open University Press).

Straub, Kristina (2009), Domestic Affairs: Intimacy, Eroticism, and Violence between Servants and Masters in Eighteenth-Century Britain (Baltimore: Johns Hopkins University Press).

Taylor, Charles (1989), Sources of the Self: The Making of Modern Identity (Cambridge, MA: Harvard University Press).

Teltscher, Kate (1995), India Inscribed: European and British Writing on India, $1600-1800$ (New Delhi: Oxford University Press).

The. Theatrical Bouquet: Containing an Alphabetical Arrangement of the Prologues and Epilogues, Which have been Published by Distinguished Wits, from the Time that Colley Cibber first came on the Stage, to the present Year (1778) (London).

Thelwall, John (1822), The Poetical Recreations of the Champion and his literary correspondents; with a selection of Essays, literary and critical, which have appeared in 'The Champion' Newspaper (London: Champion Press).

(1978, 1793), The Peripatetic or, Sketches of the Heart, of Nature and Society, in a Series of Politico-Sentimental Journals, in Verse and Prose, of the Eccentric Excursions of Sylvanus Theophrastus, Donald H. Reiman (ed.), 3 vols in 2 (repr. New York: Garland).

(1995a, 1795), 'The Present War a principal cause of the Starving Condition of the People'. - The first Lecture 'On the causes of the Dearness and Scarcity of Provisions', The Tribune, no. XVI, delivered Wednesday, April 29, in Claeys, 136-61.

- $(1995 \mathrm{~b}, 1795)$, 'The Second Lecture on the Causes of the present Dearness and Scarcity of Provisions', The Tribune, no. XVII, delivered Friday, May 1, in Claeys, $162-81$.

(1995c, 1795), 'A Warning Voice to the Violent of All Parties; with Reflections on the Events of the First Day of the present Session of Parliament; and an Enquiry whether Conciliatory or Coercive Measures are best calculated to allay Popular Ferments', The Tribune, no. XLVII, delivered Friday, Nov. 6, in Claeys, 314-27.

(1995d, 1796), Sober Reflections on the Seditious and Inflammatory Letter of the Right Hon. Edmund Burke, To a Noble Lord, in Claeys, 329-87.

- (1995e, 1796), The Rights of Nature, Against the Usurpations of Establishments, in Claeys, 389-500.

- (2001, 1793), The Peripatetic, Judith Thompson (ed.) (Detroit: Wayne State University).

Thiel, Udo (2005), 'Self-Consciousness and Personal Identity', in Knut Haakonssen (ed.), The Cambridge History of Eighteenth-Century Philosophy (Cambridge: Cambridge University Press), 286-318.

Thompson, Edward P. (1968), The Making of the English Working Class (Harmondsworth: Penguin). 
Thompson, Judith (1998), 'John Thelwall and the Enfranchisement of Literature', in Tilottama Rajan and Julia M. Wright (eds), Romanticism, History and the Possibilities of Genre: Re-forming literature, 1789-1837 (Cambridge: Cambridge University Press), 122-48.

- (2001), 'Introduction', in Judith Thompson (ed.), John Thelwall's The Peripatetic (Detroit: Wayne State University), 11-61.

Thompson, Martyn P. (1987), Ideas of Contract in English Political Thought in the Age of John Locke (New York, London: Garland).

Tillyard, Stella (2005), 'Celebrity in 18th-Century London', History Today (June): 20-27.

Tobin, Beth Fowkes (1999), Picturing Imperial Power: Colonial Subjects in Eighteenth-Century British Painting (Durham: Duke University Press).

Todd, Janet (1986), Sensibility: An Introduction (London: Methuen).

Tosh, John (1999), "The Old Adam and the New Man: Emerging Themes in the History of English Masculinities, 1750-1850', in Tim Hitchcock and Michèle Cohen (eds), English Masculinities, 1660-1800 (Harlow: Longman), 217-38.

'The Trial of Ford Lord Grey of Werk, Robert Charnock, Anne Charnock, David Jones, Frances Jones, and Rebecca Jones, at the King's Bench, for a Misdemeanour, in Debauching the Lady Henriette, daughter of the Earl of Berkeley', Nov. 23, 1682' (1730), A complete collection of state-trials, and proceedings for high treason, and other crimes and misdemeanours; from the reign of King Richard II. to the end of the reign of King George I, 6 vols (London), 515-41.

Tufte, Edward R. (2003), Envisioning Information (Cheshire, CT: Graphic Press).

Tully, James (1988), 'Governing Conduct', in Edmund Leites (ed.), Conscience and Casuistry in Early Modern Europe (Cambridge: Cambridge University Press), 12-71.

Turner, Cheryl (1994), Living by the Pen: Women Writers in the Eighteenth Century (London: Routledge).

Van Sant, Ann Jessie (1993), Eighteenth-Century Sensibility and the Novel: The Senses in Social Context (Cambridge: Cambridge University Press).

Vanbrugh, John (1982, 1697), The Provoked Wife (Manchester: Manchester University Press).

Varisco, Daniel Martin (2007), Reading Orientalism: Said and the Unsaid (Seattle: University of Washington Press).

Vickery, Amanda (1993), 'Golden Age to Separate Spheres? A Review of the Categories and Chronology of English Women's History', Historical Journal 36: 383-414.

Wagner, Peter (1990), Eros Revived: Erotica of the Enlightenment in England and America (London: Paladin).

— (1991), 'Hogarth's Graphic Palimpsests: Intermedial Adaptation of Popular Literature', Word and Image 7.4: 329-47. 
(1994), 'Der Leser und Lesestoffe im graphischen Werk William Hogarths', in Paul Goetsch (ed.), Lesen und Schreiben im 17. und 18. Jahrhundert: Studien zu ihrer Bewertung in Deutschland, England, Frankreich (Tübingen: Narr), 223-41.

(1996), 'How to (Mis)read Hogarth - or Ekphrasis Galore', 1650-1850: Ideas, Aesthetics, and Inquiries in the Early Modern Era 2: 203-40.

(1997), 'The Artist at Work: A (De)constructive View of Hogarth's Beer Street', in Frédéric Ogée (ed.), The Dumb Show: Image and Society in the Works of William Hogarth (Oxford: The Voltaire Foundation), 100-127. $7-32$.

(2001b), 'Hogarthian Frames: The New Eighteenth-Century Aesthetics', in David Bindman, Frédéric Ogée, and Peter Wagner (eds), Hogarth: Representing Nature's Machines (Manchester: Manchester University Press), 23-46.

Wahrman, Dror (2004), The Making of the Modern Self: Identity and Culture in Eighteenth-Century England (New Haven: Yale University Press).

Wainwright, V.L. (1990), 'Lending to the Lord: Defoe's Rhetorical Design in A Journal of the Plague Year', British Journal of Eighteenth-Century Studies 13: 59-72.

Wallace, Anne D. (1993), Walking, Literature, and English Culture: The Origins and Uses of Peripatetic in the Nineteenth Century (Oxford: Clarendon).

Warraq, Ibn (2007), Defending the West (New York: Prometheus Books).

Watt, Ian (1987), The Rise of the Novel: Studies in Defoe, Richardson and Fielding (repr. London: Hogarth).

Weber, Harold (1996), Paper Bullets: Print and Kingship under Charles II (Lexington: University Press of Kentucky).

Weidle, Roland (2005), 'Negotiations of Personal Identity in Eighteenth-Century Domestic Tragedy: John Locke, George Lillo and Edward Moore', Anglistik 16.2: $35-48$.

Weil, Rachel (1999), Political Passions: Gender, the Family and Political Argument in England, 1680-1714 (Manchester: Manchester University Press).

Weimann, Robert (2000), Author's Pen and Actor's Voice: Playing and Writing in Shakespeare's Theatre, Helen Higbee and William West (eds) (Cambridge: Cambridge University Press).

West, Russell (2001), 'To the Unknown Reader: Constructing Absent Readership in the Eighteenth-Century Novel: Fielding, Sterne and Richardson', Arbeiten aus Anglistik und Amerikanistik 26.2: 105-23.

Wharam, Alan (1992), The Treason Trials, 1794 (Leicester: Leicester University Press).

Wheatley, Henry B. and Peter Cunningham (1891), London Past and Present, 3 vols (London: John Murray).

Wheeler, Roxann (2000), The Complexion of Race: Categories of Difference in Eighteenth-Century British Culture (Philadelphia: University of Pennsylvania Press). 
White, Thomas (1702), A Little Book for Little Children: Wherein are set down Several Directions for Little Children, 12th edn (London).

The Whole Proceedings against Robert Earl of Oxford and Earl of Mortimer (1715) (London).

Wiesenthal, Christine S. (1992), 'Representation and Experimentation in the Major Comedies of Richard Brinsley Sheridan', Eighteenth-Century Studies 25.3: 309-30.

Wilkinson, Tate (1790), Memoirs of his own Life, 4 vols (York).

Williams, Raymond (1977), Marxism and Literature (Oxford: Oxford University Press).

Wilson, Kathleen (1995), The Sense of the People: Politics, Culture and Imperialism in England, 1715-1785 (Cambridge: Cambridge University Press).

Wind, Edgar (1938), 'The Revolution of History Painting', Journal of the Warburg Institute 2.1: 116-27.

Womersley, David (2005), 'Confessional Politics in Defoe's Journal of the Plague Year', in David Womersley, Paddy Bullard, and Abigail Williams (eds), 'Cultures of Whiggism': New Essays on English Literature and Culture in the Long Eighteenth Century (Newark: University of Delaware Press), 237-56.

Wood, Gillen D'Arcy (2001), The Shock of the Real: Romanticism and Visual Culture, 1760-1860 (New York: Palgrave).

Woodward, Josiah (1701), Account of the Rise and Progress of the Religious Societies in the City of London, etc., and of their endeavours for reformation of manners (London).

Wordsworth, William (1926, 1850), The Prelude or Growth of a Poet's Mind, Ernest de Selingcourt (ed.) (Oxford: Clarendon).

Wordsworth, William and Samuel Taylor Coleridge (1991, 1798, and 1800), Lyrical Ballads. The text of the 1798 edition with the additional 1800 poems. and the Prefaces, R.L. Brett and A.R. Jones (eds) (London: Routledge).

Worth, Katharine (1992), Sheridan and Goldsmith (Houndmills: Macmillan).

Young, Edward (1759), Conjectures on Original Composition. In a Letter to the Author of Sir Charles Grandison, 2nd edn (London: A. Millar and R. and J. Dodsley).

Zaret, David (2000), Origins of Democratic Culture: Printing, Petitions, and the Public Sphere in Early Modern England (Princeton: Princeton University Press).

Zimmerman, Everett (1992), 'H.F.'s Meditations', in Paula R. Backscheider (ed.), Daniel Defoe: A Journal of the Plague Year (New York: Norton), 285-95.

Zipes, Jack (2006), Fairy Tales and the Art of Subversion: The Classical Genre for Children and the Process of Civilization, 2nd edn (New York: Routledge).

Zorn, Carsten (2007), 'Die Simpsons der Gesellschaft: Selbstbeschreibungen moderner Gesellschaft und die Populärkultur', in Christian Huck and Carsten Zorn (eds), Das Populäre der Gesellschaft: Systemtheorie und Populärkultur (Wiesbaden: VS Verlag), 73-96. 